\title{
Chemical composition of the essential oil of Psidium guajava leaves and its toxicity against Sclerotinia sclerotiorum
}

\section{Composição química do óleo essencial de folhas de Psidium guajava e sua toxicidade contra Sclerotinia sclerotiorum}

\author{
Elizabeth Aparecida Josefi Silva ${ }^{1 *}$; Vanessa Paula da Silva ${ }^{2}$; \\ Cassia Cristina Fernandes Alves ${ }^{3}$; José Milton Alves ${ }^{4}$; Edson Luiz Souchie ${ }^{5}$; \\ Luiz Cláudio Almeida Barbosa ${ }^{6}$
}

\begin{abstract}
Globally, the fungus Sclerotinia sclerotiorum is considered as one of the most important phytopathogens, since it affects the production of several economically important crops. Further, it is difficult to control, thus increasing the use of pesticides. Therefore, the search for new substances, especially those extracted from plants, has received special attention to control this plant pathogen. The objective of the present study was to evaluate the yield and chemical composition of the essential oil extracted from the fresh leaves of guava collected during the rainy and dry seasons, and also to evaluate its toxicity against $S$. sclerotiorum. The experiment was a completely randomized design with five treatments and six replicates. The essential oil was extracted by hydrodistillation of the leaves and analyzed by gas chromatography-flame ionization detector and gas chromatography-mass spectrometry. The main compounds identified in the essential oil were trans-caryophyllene and $\alpha$-humulene. The essential oil at a concentration of $300 \mu \mathrm{L}$ exhibited $90 \%$ inhibition of the mycelial growth of S. sclerotiorum. This confirmed the antifungal potential of the essential oil of the guava leaves during both the sampling seasons.
\end{abstract}

Key words: Antifungal activity. Pathogenic fungi. Psidium guajava. Secondary metabolite. Sesquiterpene.

\section{Resumo}

O fungo Sclerotinia sclerotiorum é considerado um dos fitopatógenos mais importantes no mundo, pois afeta a produção de diversas culturas de importância econômica, e possui difícil controle, aumentando, assim, a necessidade de crescentes aplicações de defensivos agrícolas. Dessa forma, a busca de novas substâncias, principalmente aquelas extraídas de plantas, tem recebido especial atenção como forma de controle desse fitopatógeno. Com este trabalho, objetivou-se avaliar o rendimento, a composição química e a toxicidade frente a $S$. sclerotiorum do óleo essencial extraído de folhas in natura de goiabeira coletadas na época das chuvas e da seca. O delineamento utilizado foi inteiramente casualizado, com cinco tratamentos e seis repetições. O óleo essencial foi extraído por hidrodestilação das folhas e analisado por CG-DIC e CG-EM. Os compostos majoritários identificados no óleo essencial

\footnotetext{
1 Discente de Doutorado em Ciências Agrária-Agronomia Instituto Federal Goiano, Campus Rio Verde, IFGoiano, RV, Rio Verde, GO, Brasil. E-mail: elizabethjosefi@yahoo.com.br

2 Discente de Mestrado em Agroquímica, IFGoiano, RV, Rio Verde, GO, Brasil. E-mail: vanessapaula221993@gmail.com

${ }^{3}$ Prof $^{\mathrm{a}}$, Dr ${ }^{\mathrm{a}}$, em Química, IFGoiano, RV, Rio Verde, GO, Brasil. E-mail: cassiacefetrv@gmail.com

4 Prof., Dr., em Agronomia/Ciências do Solo, IFGoiano, RV, Rio Verde, GO, Brasil. E-mail: jmiltonalves@gmail.com

5 Prof., Dr., em Agronomia/Solo e Água, IFGoiano, RV, Rio Verde, GO, Brasil. E-mail: edson.souchie@ifgoiano.edu.br

6 Prof., Dr., em Química, IFGoiano, RV, Rio Verde, GO, Brasil. E-mail: lcab@outlook.com

* Author for correspndence
} 
foram o trans-cariofileno e $\alpha$-humuleno. O óleo essencial possibilitou taxa de inibição micelial de $S$. sclerotiorum acima de $90 \%$ com o tratamento de $300 \mu \mathrm{L}$, confirmando o potencial antifúngico do óleo essencial de folhas de goiabeira em ambas as épocas de coleta avaliadas.

Palavras-chave: Atividade antifúngica. Fungos fitopatogênicos. Metabólitos secundários. Psidium guajava. Sesquiterpenos.

The white mold (or stem rot) disease is caused by the fungus Sclerotinia sclerotiorum. The disease receives its name due to the presence of watersoaked, brown, soft lesions in the affected organs, with a white cotton-like mycelium covering parts of the tissue (JULIATTI et al., 2013). Controlling this pathogen is difficult due to the presence of resistant structures known as sclerotia, which can remain viable for up to 11 years. Further, the fungicides normally used have not been proven to be efficient (GRABICOSKI et al., 2010; JULIATTI et al., 2013).

Though they are only partially effective, the control of this fungus still depends on the use of chemical fungicides (ULOTH et al., 2013). However, the use of fungicides has become increasingly restricted (NIU et al., 2011; XIE et al., 2011), as its indiscriminate application causes serious risks for human and animal health, and contaminates the soil and water. In addition, there is the problem of pathogens developing resistance against the fungicides (BOMFIM et al., 2015).

There is an urgent need to identify alternative, effective, and safe sources to control S. sclerotiorum (ULOTH et al., 2013). Therefore, the interest in secondary metabolites and essential oils of plants has increased in the last decade. This is due to the ease of acquisition, low cost, and absence of problems inherent to synthetic chemical products (KUMAR et al., 2014; BOMFIM et al., 2015).

Recently, several studies on the antifungal action of the essential oils have been reported. Notably, the essential oil extracted from the leaves of Psidium guajava, popularly known as guava tree, belonging to the family Myrtaceae. This species grows in tropical and subtropical climates, being well adapted to a variety of soil types. It has medicinal properties, its bark has been employed in the treatment of diarrhea in children and leaves are used for relieving cough, pulmonary disorders, wounds, and ulcers. Further, its fruit is used as a tonic and an anthelmintic agent (BISWAS et al., 2013).

Results from the literatures attest that the oil extracted from the guava leaves has antibacterial activity against Staphylococcus aureus and Salmonella anatum and repellent activity against cockroaches. Further, it has moderate repellent activity against the mosquito Anopheles stephensi Liston, and anti-inflammatory and antifungal activities against Colletotrichum gloeosporioides (THAVARA et al., 2007; RAJKUMAR; JEBANESAN, 2007; GONÇALVES et al., 2008; SILVA et al., 2009).

There are reports on the control of diseases by the use of essential oils derived from various plants. However, there are only a few studies on the antifungal potential of the essential oil of the guava leaves and alternative methods for the control of $S$. sclerotiorum, both in vitro and in vivo. Therefore, it is necessary to conduct studies in this direction. These studies should aim at identifying alternative methods for the control of $S$. sclerotiorum. In this milieu, the present work was conducted to evaluate the yield and chemical composition of the essential oil extracted from the leaves of P. guajava. Further, the antifungal activity of the essential oil was evaluated against the phytopathogen $S$. sclerotiorum.

The guava leaves were collected from the Federal Institute of Goiás (GO), Rio Verde Campus (latitude $17^{\circ} 47^{\prime} 26.43^{\prime \prime} \mathrm{S}$, longitude 5054'49.597' $\mathrm{W}$, and altitude $720 \mathrm{~m}$ ). The region has well defined rainy and dry seasons (MALHEIROS, 2004). The guava leaves were sampled in a single collection in the months of January (rainy season) and July (dry season) 2014 between 6 and 8 am. The leaves were 
collected from the upper and lower thirds of the plant. The plant was identified, and a sample has been deposited (registration number 4481) in the herbarium of the State University of Montes Claros, Minas Gerais, Brazil. The collected leaves were placed in plastic bags and brought to the Chemistry Laboratory of Natural Products of the Federal Institute of Goiás, Rio Verde Campus. The leaves were then selected and homogenized; the leaves that were in a poor condition were discarded.

The essential oil was extracted in $3 \mathrm{~L}$ volumetric flask by hydrodistillation using a Clevenger device for a period of $2 \mathrm{~h}$ starting from the point of ebullition (SIQUEIRA et al., 2011). During each collection season, the extraction of oil was performed using $6 \mathrm{~kg}$ of leaves. The essential oil was extracted from the aqueous phase through liquid-liquid extraction using dichloromethane $\left(\mathrm{CH}_{2} \mathrm{Cl}_{2}\right)$. The hydrosol was washed thrice with $50 \mathrm{~mL}$ of $\mathrm{CH}_{2} \mathrm{Cl}_{2}$. The essential oil extracted was dehydrated using sodium sulfate anhydrous, collected in amber-colored glass flasks, and maintained in a refrigerator for subsequent identification of its chemical composition and testing on the phytopathogen.

To quantify the components of the essential oil, a Shimadzu GC-17A gas chromatograph equipped with a flame ionization detector (GCFID) and SPB-5 fused silica capillary column (30 $\mathrm{m} \times 0.25 \mathrm{~mm}, 0.25 \mu \mathrm{m}$ film thickness) was used. The chromatographic conditions included: nitrogen carrier gas with a flow rate of $1.8 \mathrm{~mL} \mathrm{~min}^{-1}$; injector and detector temperatures of $220^{\circ} \mathrm{C}$ and $240{ }^{\circ} \mathrm{C}$, respectively; initial column temperature of $40{ }^{\circ} \mathrm{C}$, initial isothermal period of $4 \mathrm{~min}$, followed by 3 ${ }^{\circ} \mathrm{C}$ per min heating up to $240{ }^{\circ} \mathrm{C}$, final isothermal period of $15 \mathrm{~min}$; sample injection volume $1.0 \mu \mathrm{L}$ (10 $\mathrm{mg} \mathrm{mL}^{-1}$ in $\mathrm{CH}_{2} \mathrm{Cl}_{2}$ ); split ratio of 1:10; column pressure of $115 \mathrm{KPa}$.

To identify the components of the essential oil, a Shimadzu GC-17A gas chromatograph equipped with a RTX-5 fused silica capillary column $(30 \mathrm{~m}$ $\times 0.25 \mathrm{~mm}, 0.25 \mu \mathrm{m}$ film thickness) coupled to a
Shimadzu CGMS-QP5050A mass spectrometer (GC-MS) was used. The chromatographic conditions were similar to those of the GC-FID analysis, except the carrier gas, which in this case was helium with a flow rate of $1.0 \mathrm{~mL} \mathrm{~min}^{-1}$, and the column pressure was $100 \mathrm{KPa}$. The electron impact technique was used for the detection of compounds, at $70 \mathrm{eV}$ with sweep amplitude of 30 to $700 \mathrm{Da}$.

The quantitative analysis of the essential oil components was performed in triplicates. The concentration of each component was calculated from the percent of the corresponding peak area in relation to the total area of all the peaks observed in the chromatogram. The identification of the components was performed through a comparison of their mass spectra and retention index (RI) with those of the standard substances from the system libraries (Wiley $7^{\text {th }}$ edition) and data from the literatures (ADAMS, 2007). The RIs were obtained using the n-alkane homologous series $\left(\mathrm{C}_{10}-\mathrm{C}_{29}\right)$ that were coinjected with the sample. The identification of the essential oil components was performed in the Laboratory of Analysis and Synthesis of Agrochemicals, Federal University of Viçosa.

The S. sclerotiorum isolate Ss12 (BRM 29673) was provided by the EMBRAPA - National Rice and Beans Research center, Santo Antônio de Goiás, GO. The culture was maintained on the potato dextrose agar (PDA) medium in an incubator at the Laboratory of Agricultural Microbiology of the Federal Institute of Goiás, Rio Verde campus, for subsequent experiments. The isolate was replated only once, that was $10 \mathrm{~d}$ before the start of the experiment.

The determination of antifungal activity of the essential oil was carried out in the Laboratory of Agricultural Microbiology of the Federal Institute of Goiás, Rio Verde campus. It was conducted according to methodology of Silva et al. (2009), with a modification in the incorporation of the essential oil in the medium. The activity of the essential oil extracted from the guava leaves, collected during 
the rainy and dry seasons, was evaluated in relation to the mycelial growth of S. sclerotiorum. The concentrations of oil used included, 100, 200, and $300 \mu \mathrm{L}$. The concentrations used were defined from preliminary tests and data from a literature, where the same oil was tested against a different species of fungus.

The medium without the essential oil of the guava leaves was used as a negative control, while the fungicide fluazinam $500 \mathrm{SC}\left(10 \mu \mathrm{g} \mathrm{mL}^{-1}\right.$ of its active ingredient) was used as a positive control. As an adaptation to the methodology used, the essential oil or fungicide was poured over the surface of a presolidified PDA medium in a Petri dish $(9 \mathrm{~cm})$ and spread with the help of a sterilized Drigalski spatula. After the incorporation of the essential oil or fungicide, $8 \mathrm{~mm}$ discs containing 10-day-old mycelium were placed to the center of the dishes. The plates were then incubated at $22 \pm 3{ }^{\circ} \mathrm{C}$ with a photoperiod of $12 \mathrm{~h}$. The first evaluation was performed after $48 \mathrm{~h}$ of incubation and continued until the negative controls exhibited complete growth. Six repetitions were performed per treatment.

The fungal growth inhibition was determined by the percent inhibition of mycelial growth (PIG) according to the formula: [(diameter of the negative control - diameter of the treatment)/diameter of the negative control) $] \times 100$, according to the method described by Edgington et al. (1971).

The experiment was set up in a completely randomized design with five treatments: positive control, negative control, and three treatments with essential oil in concentrations of 100, 200, and 300 $\mu \mathrm{L}$. Six repetitions for each season of leaf collection (rainy and dry) was carried out. The data were analyzed by analysis of variance, and the means were compared using the Tukey test (5\%), with the software Assistat version 7.7 beta.

In the present study, the amounts of essential oil extracted from the guava leaves were $0.11 \%$ and $0.08 \%$ during the rainy (January 2014) and dry (July
2014) seasons, respectively. The higher essential oil content observed during the rainy season than that during the dry season can be attributed to the climactic conditions. The average temperature (29 ${ }^{\circ} \mathrm{C}$ ) and relative humidity (70\%) were relatively high in January offering favorable conditions for the production of essential oil (BRANT et al., 2008). Further, the long summer days might have been an influencing factor, as well, offering conditions conducive for the vegetative growth of the plants.

In the present study, the reduction in the essential oil content observed during the winter, a season (June-August) that is predominantly dry, might be due to the activation of the natural source-sink regulation mechanism. During which, the secondary metabolites are degraded, and the chemical compounds so obtained are directed towards the maintenance of the primary metabolism (TAIZ; ZEIGER, 2004). Thus, decreasing the essential oil content in the guava leaves during the dry season. Similar results were obtained by Botrel et al. (2010), while evaluating the influence of seasons on the essential oil content of Hyptis marrubioides. They observed relatively high $(0.42 \%)$ and low $(0.27 \%)$ oil yields during the summer and winter seasons, respectively. Conversely, Reis et al. (2010) in their study on the essential oil of arnica (Lychnophora pinaster) recorded relatively low essential oil yield $(0.29 \%)$ during the summer season. These studies reveal that the essential oil yield in relation to seasons varies considerably between medicinal plant species.

The results of the chemical composition analysis of the essential oil of the guava leaves, collected during the rainy and dry seasons, have been presented in Table 1. A total of 17 and 16 compounds were identified in the essential oil of the guava leaves collected during the rainy and dry seasons, respectively. Similar results were reported by Craveiro et al. (1981) in their study on the chemical composition of the essential oil of the guava leaves. 
Table 1. Chemical composition of the essential oil of Psidium guajava leaves collected during the rainy (January 2014) and dry (July 2014) seasons.

\begin{tabular}{|c|c|c|c|}
\hline \multirow{2}{*}{ Compounds } & \multirow{2}{*}{$\mathbf{R I}^{*}$} & \multicolumn{2}{|c|}{ Percent (\%) } \\
\hline & & Rainy season & Dry season \\
\hline \multicolumn{4}{|c|}{ Monoterpene hydrocarbons (\%) } \\
\hline Limonene & 1024 & 2.22 & - \\
\hline \multicolumn{4}{|c|}{ Oxygenated monoterpenes (\%) } \\
\hline 1,8-cineole & 1026 & 1.50 & - \\
\hline \multicolumn{4}{|c|}{ Sesquiterpene hydrocarbons (\%) } \\
\hline$\alpha$-Copaene & 1374 & 0.32 & 1.16 \\
\hline trans-Caryophyllene & 1419 & 18.90 & 13,44 \\
\hline$\alpha$-Humulene & 1454 & 26.37 & 18.74 \\
\hline Aromadendrene & 1488 & 7.63 & 3.14 \\
\hline$\alpha$-Clovene & 1468 & - & 3.29 \\
\hline 4,11-selinadiene & 1475 & 0.29 & - \\
\hline$\gamma$-Muurolene & 1478 & 1.30 & 0.92 \\
\hline$\beta$-Selinene & 1489 & - & 11.65 \\
\hline$\alpha$-Selinene & 1497 & 11.39 & 3.93 \\
\hline$\beta$-Bisabolene & 1505 & - & 0.19 \\
\hline$\alpha$-Panasinsene & 1517 & 0.34 & - \\
\hline$\partial$-Cadinene & 1524 & - & 0.20 \\
\hline \multicolumn{4}{|c|}{ Oxygenated sesquiterpenes (\%) } \\
\hline trans-Nerolidol & 1566 & 2.91 & 3.87 \\
\hline Caryophyllene oxide & 1585 & 3.42 & 2.16 \\
\hline$\alpha$-Humulene epoxide II & 1612 & 2.37 & 1.75 \\
\hline Longipinene epoxide & 1620 & 0.97 & - \\
\hline epi- $\alpha$-Muurolol & 1639 & 3.08 & - \\
\hline$\alpha$-Cadinol & 1651 & 1.07 & - \\
\hline Isoaromadendrene epoxide & 1612 & - & 8.77 \\
\hline Selin-11-en-4 $\alpha$-ol & 1662 & 8.75 & 10.52 \\
\hline cis-Z- $\alpha$-Bisabolene epoxide & 1698 & - & 0.20 \\
\hline Monoterpenes & & 3.72 & - \\
\hline Sesquiterpenes & & 89.11 & 85.93 \\
\hline Total number of compounds & & 17 & 16 \\
\hline
\end{tabular}

RI* Retention index obtained with reference to the n-alkane homologous series using an SPB-5 column.

- Compound not identified.

In the present study, the sesquiterpenes were the predominant compounds identified in the essential oil of the guava leaves collected during both the seasons. The main compounds identified in the essential oil of the leaves collected during the rainy season were trans-caryophyllene (18.90\%), $\alpha$-humulene
(26.37\%), $\alpha$-selinene $(11.39 \%)$, and selin-11-en$4 \alpha$-ol $(8.75 \%)$. While the sesquiterpenes, transcaryophyllene (13.44\%), $\alpha$-humulene (18.74\%), $\beta$-selinene (11.65\%), isoaromadendrene epoxide $(8.77 \%)$, and selin- 11 -en- $4 \alpha$-ol $(10.52 \%)$ were the main compounds identified in the oil of the guava 
leaves collected during the dry season.

The monoterpenes, 1,8-cineole and limonene, and sesquiterpenes, trans-caryophyllene, $\alpha$-humulene, and caryophyllene oxide, were detected in the essential oil of the guava leaves. Similar results were recorded by Craveiro et al. (1981), while characterizing the essential oil of the guava leaves. Further, a study has indicated that 1,8-cineole, limonene, trans-caryophyllene, $\alpha$-humulene, and other terpenes have fungicidal potential (PINO et al., 2001).

In the present study, a reduction in the relative concentrations of trans-caryophyllene and $\alpha$-humulene was observed in the essential oil obtained during the rainy season when compared with those of the essential oil obtained during the dry season. The reductions were from $18.90 \%$ to $13.44 \%$ and $26.37 \%$ to $18.74 \%$ for trans-caryophyllene and $\alpha$-humulene, respectively. Further, $\alpha$-selinene was not detected in the essential oil obtained during the dry season. On the other hand, the concentration of selin-11-en- $4 \alpha$-ol increased from $8.75 \%$ to $10.52 \%$ in the essential oil obtained during the dry season in comparison with that of the essential oil obtained during the rainy season. The main components of the essential oil of the leaves collected during the dry and rainy seasons were similar, except for the absence of $\alpha$-selinene and presence of $\beta$-selinene and isoaromadendrene epoxide in the oil obtained during the dry season.

The differences observed in the composition of the essential oil of the guava leaves collected during the two seasons might be due to the environmental factors, season, and time of sampling (OLIVEIRA et al., 2011). Secondary metabolites represent a mode of chemical communication between the plants and its environment. The stimuli that a plant receives from its environment might influence the direction of the metabolic pathways resulting in the biosynthesis of different compounds. Therefore, the chemical composition and essential oil content of the plants might exhibit variations between seasons (MORAIS, 2009).

The results of the activity of the essential oil of the guava leaves, collected during the rainy and dry seasons, on the mycelial growth of $S$. sclerotiorum have been represented in Figure 1. The essential oils of the guava leaves inhibited the mycelial growth by more than $90 \%$.

A comparison of PIG was made between the treatments. The concentrations of oil used in different treatments-100, 200, and $300 \mu \mathrm{L}$ were similar to those used by Silva et al. (2009). The PIG of the essential oil extracted from guava leaves collected during the rainy season revealed statistical difference between each treatment. A more pronounced effect with $94.9 \%$ inhibition of mycelial growth was observed at a concentration of $300 \mu \mathrm{L}$ when compared with that of the $100 \mu \mathrm{L}$ concentration that resulted in $77.5 \%$ inhibition. The concentrations of 200 and $300 \mu \mathrm{L}$ of the guava leaf essential oil resulted, respectively, in 90.8\% and $94.9 \%$ inhibition of the mycelial growth of $S$. sclerotiorum. Thus, proving $300 \mu \mathrm{L}$ to be the most efficient of the concentrations used in the present study. These results confirmed the toxicity of the important metabolites present in the essential oil of the guava leaves. Further, the PIG of different concentrations of oil was compared with the positive control, the fungicide fluazinam $500 \mathrm{SC}(10 \mu \mathrm{L})$, which exhibited $100 \%$ mycelial growth inhibition. 
Figure 1. Percent of mycelia growth inhibition of the fungus Sclerotinia sclerotiorum by the fungicide fluazinam 500 SC and different concentrations of the essential oil of the guava leaves extracted during the rainy (January 2014) and dry (July 2014) seasons. *Means followed by the same letter did not differ significantly according to the Tukey test $(5 \%)$, with each extraction season being evaluated separately. The bars in the columns represent the standard deviation.

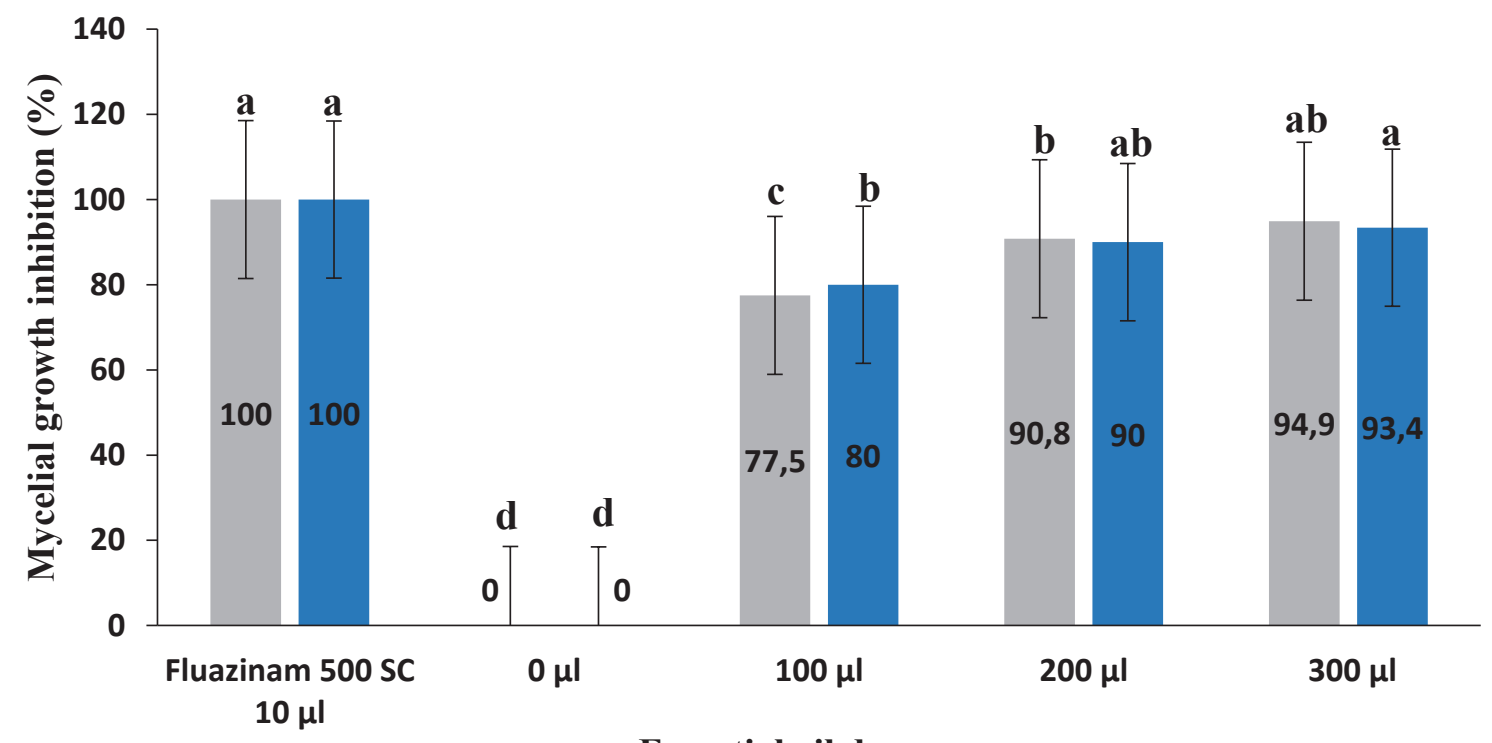

Essential oil doses

Rain Dry

The PIG of the essential oil extracted from the guava leaves collected during the dry season (Figure 1) revealed that the concentrations 100 and $200 \mu \mathrm{L}$ were not statistically different. Similarly, no statistical difference in the PIG was observed between the concentrations 200 and $300 \mu \mathrm{L}$ of essential oil. However, there was a statistical difference in the PIG between the concentrations 100 and $300 \mu \mathrm{L}$ of essential oil. The essential oil of concentrations 100,200 , and $300 \mu \mathrm{L}$ resulted in $80 \%, 90 \%$, and $93.4 \%$ inhibition of mycelial growth, respectively. This demonstrated the toxicity of this essential oil at a concentration of above 100 $\mu \mathrm{L}$ against $S$. sclerotiorum.

A comparison of the efficiency of the essential oils extracted during the rainy and dry seasons revealed that both the oils were effective against S. sclerotiorum. Mycelial growth inhibition of 94.9\% and $93.4 \%$ were exhibited by the essential oil extracted from the leaves collected during the rainy and dry seasons, respectively, even though the chemical composition of the oil differed between the two seasons.

According to Souza et al. (2005), the mode of action that results in the inhibition of the growth of microorganisms by essential oils involves numerous mechanisms depending on the main components of the essential oil. It is noteworthy that lipophilicity is an important characteristic of essential oils, allowing them to pass through the cell wall and cytoplasmic membrane by breaking through different layers of polysaccharides, fatty acids, and phospholipids. Thus, they alter the permeability of the organelles, and directly affect the intracellular $\mathrm{pH}$ and balance of inorganic ions (BAKKALI et al., 2008).

The novelty of the present study was in the use of the essential oil obtained from the guava leaves against S. sclerotiorum, and the results obtained were promising. Analogous results were observed in a study conducted to evaluate the effect of 
the compounds derived from various plants on Colletotrichum gloeosporioides Penz. (SILVA et al., 2009). Among the oils and extracts evaluated, the essential oil of the guava leaves at the concentration of $100 \mu \mathrm{L}$ exhibited $100 \%$ inhibition of the fungal mycelial growth. Another important aspect of using essential oils to control pathogens is that the possibility of the pathogenic microorganisms developing resistance to the essential oils is very low. Because, these essential oils are a complex mixture of antifungal substances, each acting via numerous mechanisms of attack. This characteristic is of strategic importance as it can be beneficial to various areas in which these oils are used (SILVEIRA et al., 2012).

Among the compounds identified in the essential oil of the guava leaves collected during the rainy and dry seasons, the sesquiterpenes, transcaryophyllene and $\alpha$-humulene were highlighted for their antibacterial, insecticidal, and fungicidal properties. In addition to their therapeutic properties, such as their use in the treatment of respiratory and inflammatory diseases (MEVY et al., 2007; FERNANDES et al., 2007; DEUS et al., 2011).

There are a few reports on the fungicidal activity of the essential oil of the guava leaves. Further, there are some reports on the fungicidal activity of its leaf extract, as well. Pessini et al. (2003) verified the antifungal and antimicrobial activities of the guava leaf extract against $S$. aureus, Bacillus subtilis, Escherichia coli, Pseudomonas aeruginosa, Candida albicans, C. krusei, C. parapsilosis, and C. tropicalis. Menezes et al. (2009) determined the fungicidal potential of the guava leaf extract against $C$. albicans. The results of the present study demonstrated the antifungal activity of the essential leaf of the guava leaves against the phytopathogen $S$. sclerotiorum. Even at a relatively low concentration $(100 \mu \mathrm{L})$ of essential oil used in the present study, mycelial growth inhibition of $77.5 \%$ was observed. This was the first time that this essential oil was tested against $S$. sclerotiorum.
The results of the present study concluded that the essential oil of the guava leaves was toxic against S. sclerotiorum. Therefore, the essential oil might be used as a tool to control agricultural plagues. The evaluation of essential oil content extracted from the guava leaves during the rainy and dry seasons revealed that the seasons had an influence on the essential oil yield. A higher oil yield $(0.11 \%)$ was observed during the rainy season that that during the dry season $(0.08 \%)$. The GC-FID and GC-MS analyses identified 17 and 16 compounds in the essential oil of the guava leaves collected during the rainy and dry seasons, respectively. The sesquiterpenes, trans-caryophyllene, $\alpha$-humulene, $\alpha$-selinene, and selin-11-en-4a-ol were the main compounds of the essential oil obtained during the rainy season. On the other hand, the sesquiterpenes, trans-caryophyllene, $\alpha$-humulene, $\beta$-selinene, isoaromadendrene epoxide, and selin-11-en- $4 \alpha-$ ol were predominant in the essential oil obtained during the dry season. The season of leaf sampling influenced both the chemical composition of the essential oil and relative concentrations of some components. This was demonstrated by the decrease in the concentrations of trans-caryophyllene and $\alpha$-selinene and increase in the concentration of selin-11-en-4 $\alpha$-ol in the present study.

The sesquiterpenes, such as trans-caryophyllene and $\alpha$-humulene, found in the essential oil of the guava leaves, have proven antibacterial, insecticidal, and fungicidal properties (PINO et al., 2001; MEVY et al., 2007; FERNANDES et al., 2007). In the present study, it was found that the essential oil $(300 \mu \mathrm{L})$ of the guava leaves collected during the rainy and dry seasons inhibited the mycelial growth of $S$. sclerotiorum by $94.9 \%$ and $93.4 \%$, respectively. This demonstrated its toxicity against the phytopathogen. Further, it was established that the season of leaf sampling did not influence the toxicity of the essential oil. Future studies are required to identify the compounds responsible for the biological activity of the essential oil of the leaves of $P$. guajava against $S$. sclerotiorum. 


\section{References}

ADAMS, R. P. Identification of essential oil components by gas chromatography/mass spectroscopy. $4^{\text {th }}$ ed. New York: Allured Publishing, 2007. 804 p.

BAKKALI, F.; AVERBECK, S.; AVERBECK, D.; IDAOMAR, M. Biological effects of essential oils - a review. Food and Chemical Toxicology, Kidlington, v. 46, n. 2, p. 446-475, 2008.

BISWAS, B.; ROGERS, K.; MCLAUGHLIN, F.; DANIELS, D.; YADAV, A. Antimicrobial activities of lead extracts of guava (Psidium guajava L.) on two gram-negative and gram-positive bacteria. International Journal of Microbiology, Bethesda, v. 1, n. 1, p. 1-7, 2013.

BOMFIM, N. S.; NAKASSUGI, L. P.; OLIVEIRA, J. F. P.; KOHIYAMA, C. Y.; MOSSINI, S. A. G.; GRESPAN, R.; NERILO, S. B.; MALLMAN, C. A.; ABREU FILHO, B. A.; MACHINSKI JÚNIOR, M. Antifungal activity and inhibition of fumonisin production by Rosmarinus officinalis L. essential oil in Fusarium verticillioides (Sacc.) Nirenberg. Food Chemistry, London, v. 166, n. 1, p. 330-336, 2015.

BOTREL, P. P.; PINTO, J. E. B. P.; FERRAZ, V.; BERTOLUCCI, S. K. V.; FIGUEIREDO, F. C. Teor e composição química do óleo essencial de Hyptis marrubioides Epl., Lamiaceae em função da sazonalidade. Acta Scientiarum: Agronomy, Maringá, v. 32, n. 3, p. 533-538, 2010.

BRANT R. S.; PINTO, J. E. B. P.; BERTOLUCCI, S. K. V.; ALBUQUERQUE, C. J. B. Teor do óleo essencial de cidrão (Aloysia triphylla (L' Hérit) Britton Verbenaceae) em função da variação sazonal. Revista Brasileira de Plantas Medicinais, Botucatu, v.10, n. 1, p. 83-88, 2008.

CRAVEIRO, A. A.; FERNANDES, A. G.; ANDRADE, C. H. S.; MATOS, F. J. A.; ALENCAR, J. W.; MACHADO, M. I. L. Óleos essenciais de plantas do Nordeste. Fortaleza: Edições UFC, 1981. 210 p.

DEUS, R. J. A.; ALVES, C. N.; ARRUDA, M. S. P. Avaliação do efeito antifúngico do óleo resina e do óleo essencial de copaíba (Copaifera multijuga Hayne). Revista Brasileira de Plantas Medicinais, Botucatu, v. 13, n. 1, p. 1-7, 2011.

EDGINGTON, L. V.; KHEW, K. L.; BARRON, G. L. Fungitoxic spectrum of benzimidazole compounds. Phytopathology, St. Paul, v. 61, n. 1, p. 42-44, 1971.

FERNANDES, E. S.; PASSOS, G. F.; MEDEIROS, R.; CUNHA, F. M.; FERREIRA, J.; CAMPOS, M. M.; PIANOWSKI, L. F.; CALIXTO, J. B. Os efeitos antiinflamatórios dos compostos de alfa-humuleno e (-) - trans-cariofileno isolados a partir do óleo essencial de Cordia verbenacea. European Journal of Pharmacology, Amsterdam, v. 569, n. 3, p. 228-236, 2007.

GONÇALVES, F. A.; ANDRADE NETO, M. ; BEZERRA, J. N. S.; MACRAE, A.; SOUSA, O. V.; FONTELES-FILHO, A. A.; VIEIRA, R. H. Antibacterial activity of guava, Psidium guajava Linnaeus, leaf extracts on diarrhea-causing enteric bacteria isolated from seabob shrimp, Xiphopenaeus kroyeri (HELLER). Revista do Instituto de Medicina Tropical de São Paulo, São Paulo, v. 50, n. 1, p. 11-15, 2008.

GRABICOSKI, E. M.; JACCOUD-FILHO, D. S.; HENNEBERG, L.; VRISMAN, C. M.; MARTINS NETO, M. O. Potencial inibitório de extratos de plantas para Sclerotinia sclerotiorum. In: CONGRESSO BRASILEIRO DE FITOPATOLOGIA / ANNUAL MEETING OF THE BRAZILIAN PHYTHOPATHOLOGICAL SOCIETY, 43., 43., 2010, Cuiaba. Resumo... Brasília: Brazilian Phytopathological Society, 2010. v. 35, p. 28-30.

JULIATTI, F. C.; CRATO, F. F.; JULIATTI, F. C.; COUTO, K. R.; JULIATTI, B. C. M. Escala diagramática para avaliação da severidade de mofo branco em soja. Bioscience Journal, Uberlândia, v. 29, n. 3, p. 676-680, 2013.

KUMAR, V.; MATHELA, C. S.; TEWARI, G.; SINGH, D.; TEWARI, A. K.; BISHT, K. S. Chemical composition and antifungal activity of essential oils from three Himalayan Erigeron species. LWT - Food Science and Technology, Amsterdam, v. 56, n. 2, p. 278-283, 2014.

MALHEIROS, R. A rodovia e os corredores da fauna do cerrado. Goiânia: UCG - Universidade Católica de Goiás, 2004. cap. 1, 172 p.

MENEZES, T. O. A.; ALVES, A. C. B. A.; VIEIRA, J. M. S.; MENEZES, S. A. F.; ALVES, B. P.; MENDONÇA, L. C. V. Avaliação in vitro da atividade antifúngica de óleos essenciais e extratos de plantas da região amazônica sobre cepa de Candida albicans. Revista de Odontologia da UNESP, São Paulo, v. 38, n. 3, p. 184-191, 2009.

MEVY, J. P.; BESSIERE, J. M.; DHERBOMEZ, M.; MILlOGO, J.; VIANO, J. Chemical composition and some biological activities of the volatile oils of a chemotype of Lippia chevalieri Moldenke. Food Chemistry, London, v. 101, n. 2, p. 682-685, 2007.

MORAIS, L. A. S. Influência dos fatores abióticos na composição química dos óleos essenciais. Horticultura Brasileira, Brasília, v. 27, n. 2, p. S4050-S4063, 2009.

NIU, B.; WANG, W.; XIE, X. Advance on the control of Sclerotinia sclerotiorum. Life Science Research, New Jersey, v. 16, n. 1, p. 537-540, 2011. 
OLIVEIRA, M. T. R.; BERBERT, P. A.; MATOS, C. R. R.; MATHIAS, L.; MOREIRA, R. O. Efeito da temperatura do ar de secagem sobre o teor e a composição química do óleo essencial de Pectis brevipedunculata. Quimica Nova, São Paulo, v. 34, n. 7, p. 1200-1204, 2011.

PESSINI, G. L.; HOLETZ, F. B.; SANCHES, N. R.; CORTEZ, D. A. G.; DIAS-FILHO, B. P.; NAKAMURA, C. V. Avaliação da atividade antibacteriana e antifúngica de extratos de plantas utilizados na medicina popular. Revista Brasileira de Farmacognosia, Curitiba, v. 13, p. 21-24, 2003. Suplemento 1.

PINO, J. A.; AGUERO, J.; MARBOT, R.; FUENTES, V. Leaf oil of Psidium guajava L. from Cuba. Journal Essential Oil Research, Carlo Stream, v. 31, n. 1, p. 6162, 2001.

RAJKUMAR, S.; JEBANESAN, A. Repellent activity of selected plant essential oils against the malarial fever mosquito Anopheles stephensi. Tropical Biomedicine, Kuala Lumpur, v. 24, n. 2, p. 71-75, 2007.

REIS, E. S.; PINTO, J. E. B. P.; BERTOLUCCI, S. K. V.; CORREAA, R. M.; PAULA, J. R.; ANDRADE, S. T.; FERRI, P. H. Seasonal variation in essential oils of Lychnophora pinaster Mart. Journal of Essential Oil Research, Carlo Stream, v. 22, n. 2, p. 147-149, 2010.

SILVA, A. C.; SALES, N. L. P.; ARAÚJO, A. V.; CALDEIRA JUNIOR, C. F. Efeito in vitro de compostos de plantas sobre o fungo Colletotrichum gloeosporioides Penz. isolado do maracujazeiro. Ciência e Agrotecnologia, Lavras, v. 33, p. 1853-1860, 2009. Edição Especial.

SILVEIRA, S. M.; CUNHA JÚNIOR, A.; SCHEUERMANN, G. N.; SECCHI, F. L.; VERRUK, S.; KROHN, M.; VIEIRA, C. R. W. Composição química e atividade antibacteriana dos óleos essenciais de Cymbopogon winterianus (citronela), Eucalyptus paniculata (eucalipto) e Lavandula angustifolia (lavanda). Revista Instituto Adolfo Lutz, São Paulo, v. 71, n. 3, p. 462-470, 2012.
SIQUEIRA, C. A. T.; OLIANI, J.; SARTORATTO, A.; QUEIROGA, C. L.; MORENO, P. R. H.; REIMÃO, J. Q.; TEMPONE, A. G.; FISCHER, D. C. H. Chemical constituents of the volatile oil from leaves of Annona coriacea and in vitro antiprotozoal activity. Revista Brasileira de Farmacognosia, Curitiba, v. 21, n. 21, p. 33-40, 2011.

SOUZA, E. L.; STAMFORD, T. L. M.; LIMA, E. O.; TRAJANO, V. N.; BARBOSA FILHO, J. M. Antimicrobial effectiveness of spices: an approach for use in food conservation systems. Brazilian Archives of Biology and Technology, Paraná, v. 48, n. 4, p. 549-558, 2005.

TAIZ, L.; ZEIGER, E. Fisiologia vegetal. Porto Alegre: Artmed, 2004. $820 \mathrm{p}$.

THAVARA, U.; TAWATSIN, A.; BHAKDEENUAN, P.; WONGSINKONGMAN, P.; BOONRUAD, T.; BANSIDDHI, J.; CHAVALITTUMRONG, P.; KOMALAMISRA, N.; SIRIYASATIEN, P.; MULLA, M. S. Repellent activity of essential oils against cockroaches (Dictyoptera: Blattidae, Blattellidae, and Blaberidae) in Thailand. Southeast Asian Journal Tropical Medicine Public Health, Bangkok, v. 38, n. 4, p. 663-673, 2007.

ULOTH, M. B.; YOU, M. P.; FINNEGAN, P. M.; BANGA, S. S.; BANGA, A. K.; SANDHU, P. S.; YI, H.; SALISBURY, P. A.; BARBETTI, M. J. New sources of resistance to Sclerotinia sclerotiorum for crucifer crops. Field Crops Research, Amsterdam, v. 154, n. 1, p. 40-52, 2013.

XIE, J.; XIAO, X.; FU, Y.; LIU, H.; CHENG, J.; GHABRIAL, S. A.; LI, G.; JIANG, D. A novel mycovirus closely related to hypoviruses that infects the plant pathogenic fungus Sclerotinia sclerotiorum. Virology, Amsterdam, v. 418, n. 1, p. 49-56, 2011. 